\title{
Biosorption of Zn (II) ions from Aqueous Solution by Immobilized Aspergillus fumigatus
}

\author{
1*JALIJA, DO; ${ }^{2}$ UZAIRU, A; ${ }^{2}$ EKWUMEMMGBO, P \\ ${ }^{1}$ Ahmadu Bello University, School of Basic and Remedial Studies, P.M.B. 6007 Funtua, Katsina State, Nigeria. \\ ${ }^{2}$ Department of Chemistry, Ahmadu Bello University, Zaria, Kaduna State, Nigeria \\ *Corresponding Author Email: danieljalija@yahoo.com
}

\begin{abstract}
The objective of this study was to investigate the biosorption of $\mathrm{Zn}$ (II) from aqueous solution by Aspergillus fumigatus immobilized in calcium alginate. The effects of adsorbent dosage, initial solution $\mathrm{pH}$, contact time and initial Zn (II) concentrations were investigated. Results were fitted to the Langmuir isotherm. The results showed an increase in biosorption efficiency with increase in biosorbent dosage. The optimum $\mathrm{pH}$ of adsorption was 5.0 while the maximum adsorption was achieved within 10 minutes at initial $\mathrm{Zn}$ (II) concentration of $1 \mathrm{mg} / \mathrm{L}$. The experimental results showed a high $\mathrm{R}^{2}(0.9070)$ value for the Langmuir isotherm. This therefore suggests that it is a monolayer adsorption. The maximum biosorption capacity was $3.55 \mathrm{mgg}^{-1}$. These results indicate that zinc metal removal by biomass of Aspergillus fumigatus immobilized in alginate is a low cost wastewater treatment option and can be effectively used in small scale treatment plants.
\end{abstract}

\section{DOI: https://dx.doi.org/10.4314/jasem.v23i11.13}

Copyright: Copyright (C) 2019 Jalija et al. This is an open access article distributed under the Creative Commons Attribution License (CCL), which permits unrestricted use, distribution, and reproduction in any medium, provided the original work is properly cited.

Dates: Received: 07 October 2019; Revised: 11 November 2019; 24 November 2019

Keywords: Biosorption, Aspergillus fumigatus, Adsorbent, Alginate, Isotherm, Langmuir

Heavy metal ions can be discharged into the environment from a variety of industrial activities (Cem and Aytas, 2009). They tend to persist and accumulate in every part of the food chain (Vijaya et $a l ., 2008)$. The removal of these metals from industrial wastewaters is a problem of increasing concern that has been mostly solved by chemical and physical methods of treatment. (Ahalya et al., 2003). These methods are however expensive and sometimes generate undesirable by-products. Biosorption is therefore seen as an alternative method that can be categorized as a green technology for heavy metal removal from industrial effluents (Wang and Chen, 2009). Biosorption is a term that describes the removal of heavy metals by passive binding to non-living biomass from an aqueous solution (Davis et al., 2003).

The process has gained importance due to its advantages over the conventional removal techniques. These advantages include the reusability of the biomaterial, low operating cost, improved selectivity for specific metals of interest, short operation time and non-production of secondary compounds which might be toxic (Spinti et al., 1995). This study has been carried to investigate the capacity of the fungus Aspergillus fumigatus, immobilized in calcium alginate, to adsorb Zinc (II) ions from aqueous solution and to determine the optimization parameters for the process.

\section{MATERIALS AND METHODS}

$1000 \mathrm{mg} / \mathrm{L}$ solution $\mathrm{Zn}$ (II) metal solution was prepared by dissolving $2.092 \mathrm{~g}$ of $\mathrm{ZnCl}_{2}$ in a small volume of distilled water in a $1 \mathrm{dm}^{3}$ volumetric flask and made up to the mark with more water. The fungal mycelia of Aspergillus fumigatus was cultured over Potato Dextrose Agar (PDA) plates. The PDA plates of the stock culture were maintained by subculturing at $4{ }^{\circ} \mathrm{C}$. The fungal biomass was cultivated in composition (g/L): $\mathrm{K}_{2} \mathrm{HPO}_{4}, 0.5 ; \mathrm{NaCl}, 0.5 ; \mathrm{MgSO}_{4}$, $0.5 ; \mathrm{NH}_{4} \mathrm{NO}_{3}, 0,5$; yeast extract, 0.5 , peptone, 10.0, glucose, 20. The $\mathrm{pH}$ of the media was adjusted to 5.0. The flask was autoclaved at $121^{\circ} \mathrm{C}$ for 15 minutes and then incubated in a rotary orbital shaker at $180 \mathrm{rpm}$ and $30{ }^{\circ} \mathrm{C}$. It was dried at $80^{\circ} \mathrm{C}$ overnight and was subsequently used for all the experiments (Pundir and Dastidar, 2010).

$100 \mathrm{ml}$ of $4 \%(\mathrm{w} / \mathrm{v})$ sodium alginate was mixed until homogenous with $2 \%(\mathrm{w} / \mathrm{v})$ solution of the fungal biomass. The mixture was stirred for 1 hour at $30^{\circ} \mathrm{C}$ and then the slurry was dropped through a $10 \mathrm{ml}$ syringe into $2 \%(\mathrm{w} / \mathrm{v}) \mathrm{CaCl}_{2}$ solution (Dong, 2004). Durable spherical beads containing the biomass were formed immediately. The beads were washed with distilled water and stored at $4{ }^{\circ} \mathrm{C}$ in distilled water until further use. The adsorption experiments were carried out by varying one parameter at a time while keeping the others constant. The parameters investigated were 
effects of adsorbent dosage, solution initial $\mathrm{pH}$, initial metal ion concentration and contact time. The experiments were carried out in $100 \mathrm{ml}$ conical flasks containing $50 \mathrm{ml}$ of solution at a constant temperature of $29^{\circ} \mathrm{C}$. The samples were agitated on a conical flask shaker at $150 \mathrm{rpm}$ at the stated conditions. After equilibrium was attained, the samples were filtered into polypropylene bottles using Whatman No1 filter paper. The residual concentrations of the $\mathrm{Zn}$ (II) ions were determined using an Atomic Absorption Spectrophotometer (AAS). The percentage metal removal (\%) was calculated using the following equation:

Removal \% $=\frac{\left(C_{o}-C_{e}\right)}{C_{o}} \times 100$

Where $C_{o}$ and $C_{e}$ are the initial and the residual (equilibrium) concentrations in $\mathrm{mg} / \mathrm{L}$, respectively. The amount of $\mathrm{Zn}$ (II) ion adsorbed was calculated from the difference between the added and equilibrium concentration by using the equation below (Babel and Opiso, 2007):

$q_{e}=\frac{V\left(C_{o}-C_{e}\right)}{M}$

Where $q_{e}$ is the amount adsorbed in $\mathrm{mg} / \mathrm{g}$ of the absorbent at equilibrium, $C_{o}$ and $C_{e}$ are the initial and the equilibrium concentrations in $\mathrm{mg} / \mathrm{L}$, respectively, $V$ is the volume in litres of the solution used during the experiment and $M$ is the mass of the adsorbent in grams.

The Langmuir adsorption isotherm is often used to estimate the maximum adsorption capacity corresponding to complete monolayer coverage on the adsorbent surface. It is expressed by the equation below.

$$
\frac{C_{e}}{q_{e}}=\frac{1}{K_{L} Q^{o}}+\frac{C_{e}}{Q^{o}}
$$

Where $\mathrm{K}_{\mathrm{L}}(\mathrm{L} / \mathrm{g})$ is a constant related to the adsorption / desorption energy and $\mathrm{Q}^{\circ}(\mathrm{mg} / \mathrm{g})$ is the maximum sorption upon complete saturation of the adsorption of the adsorbent (biosorbent) surface (Horsfall et al., 2004). A graph of $C_{e} / q_{e}$ against $C_{e}$ will have $K_{L}(L / g)$ as the slope and $\mathrm{Q}^{\circ}(\mathrm{mg} / \mathrm{g})$ as the intercept.

\section{RESULTS AND DISCUSSION}

Effect of adsorbents dosage on percentage removal of $\mathrm{Zn}$ (II) was investigated by varying the adsorbent dosage from $10 \mathrm{mg}$ to $200 \mathrm{mg}$ while keeping the other parameters constant. The result is presented in Fig 1. The highest percentage removal of $97.26 \%$ was achieved at $150 \mathrm{mg}$ biomass weight after which there was no further increase. The increase in percentage removal of $\mathrm{Zn}$ (II) with increase in adsorbent dosage is due to the fact with increase in adsorbent dosage, more and more surface becomes available for solutes to adsorb and this increases the rate of biosorption. When an optimum amount has been adsorbed, the rate of biosorption decreases and desorption comes into play which considerably reduces the overall rate of removal. The adsorbed ions either block the access to initial pores or cause particles to aggregate, thereby reducing the active site availability (Garg et al., 2004).

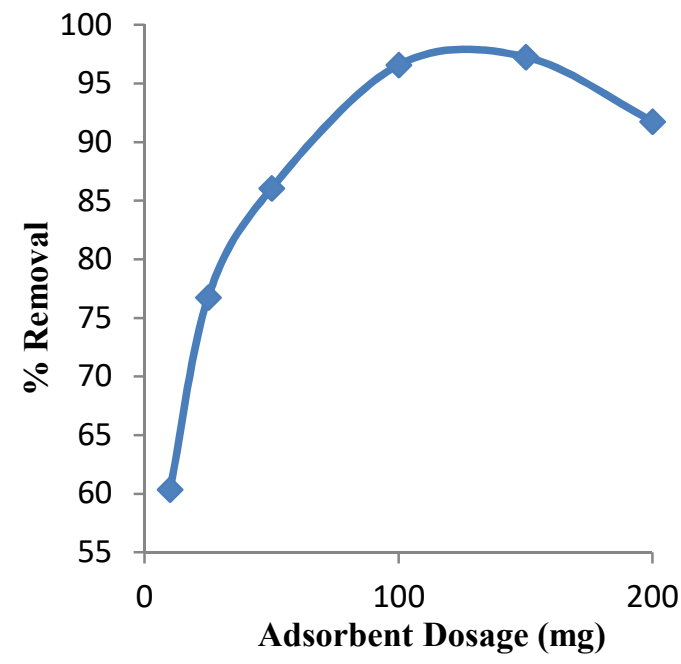

Fig 1 Effect of adsorbent dosage on Zn (II) removal by alginate immobilized Aspergillus fumigatus

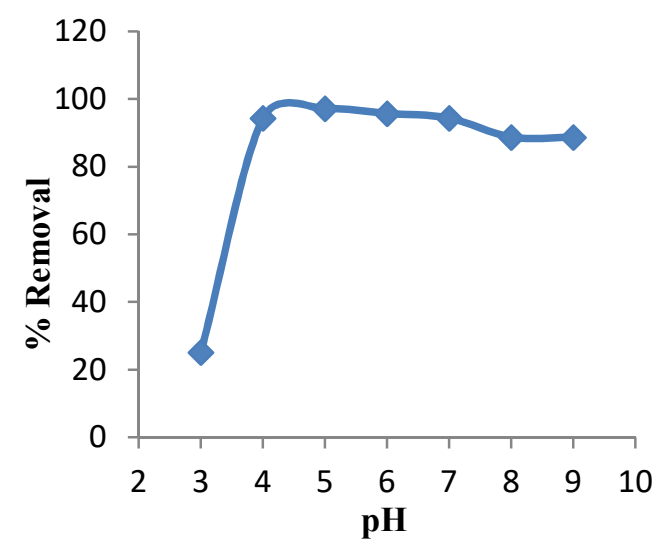

Fig 2 Effect of solution $\mathrm{pH}$ on the removal of $\mathrm{Zn}$ (II) by alginate immobilized Aspergillus fumigatus

The effect of the $\mathrm{pH}$ on the removal of $\mathrm{Zn}$ (II) ions from solution is presented in Fig 2. The removal percentage increased from $25.14 \%$ at $\mathrm{pH} 3.0$ to $97.17 \%$ at $\mathrm{pH} 5.0$ after which there was a decrease. At lower $\mathrm{pH}$, heavy metal biosorption decreases due to the positive charge density on metal binding sites i.e. hydrogen ions compete effectively with metal ions in binding to the sites. And with increasing $\mathrm{pH}$, the negative charge density on the adsorbent surface increases due to deprotonation of the metal binding 
sites. The metal ions then compete more effectively for available binding sites, which increases biosorption (Kapoor and Viraraghvan, 1997).

The effect of the contact time on the removal of $\mathrm{Zn}$ (II) ions from solution is presented in Fig 3. From the figure it can be seen that the removal percentage of the $\mathrm{Zn}$ (II) ions by Aspergillus fumigatus was highest at 10 minutes contact time followed by a marginal decrease afterwards. When an optimum amount had been sorbed, the rate of adsorption decreased and desorption came into play which considerably reduced the overall rate of reaction. The adsorbed ions either blocked access to initial pores or caused particles to aggregate, thereby reducing the active site availability (Garg et al., 2004).

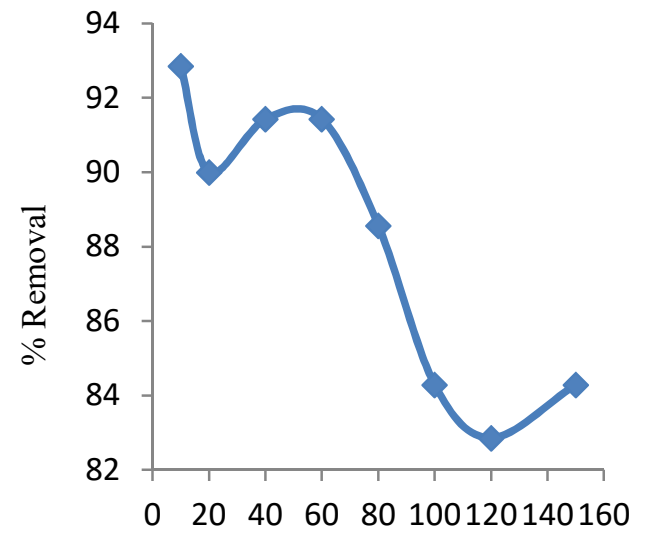

Contact Time (mins)

Fig 3 Effect of contact time on the removal of Zn (II) by alginate immobilized Aspergillus fumigatus

The effect of initial metal ion concentration on the removal of $\mathrm{Zn}$ (II) ions from solution is shown in the Fig 4. From the figure it can be seen that the removal percentage of $\mathrm{Zn}$ (II) ions by Aspergillus fumigatus increased from $70.11 \%$ at $1 \mathrm{mg} / \mathrm{L}$ to $79.90 \%$ at $6 \mathrm{mg} / \mathrm{L}$ after which it began to decrease. At lower concentrations, $\mathrm{Zn}$ ions in the solution would interact with the binding sites and thus facilitated high adsorption efficiency. At higher concentrations, more $\mathrm{Zn}$ ions are left un-adsorbed in solution due to the saturation of binding sites. This indicates that energetically less favourable sites become involved with increasing ion concentrations in the aqueous solution (Arias and Sen, 2009). Similar results have been reported by Amuda et al. (2007). The Langmuir isotherm for the biosorption of $\mathrm{Zn}$ (II) by alginate immobilized A. fumigatus is shown in Fig 5. The value of the coefficient of determination, $\mathrm{R}^{2}$, was found to be 0.9072 . The $\mathrm{R}^{2}$ value is close to unity. It, therefore, exhibits a good fit of the equilibrium data for the
Langmuir model. Maximum biosorption capacity $\mathrm{Q}^{\circ}$ was calculated to be $3.55 \mathrm{mg} \mathrm{g}^{-1}$.

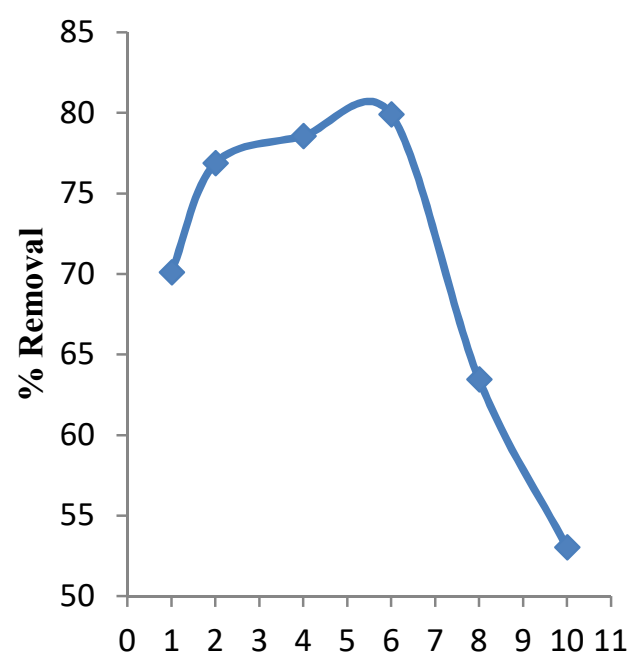

Initial Metal ion Conc. (mg/L)

Fig 4 Effects of initial metal ion concentration on $\mathrm{Zn}$ (II) removal by alginate immobilized Aspergillus fumigatus

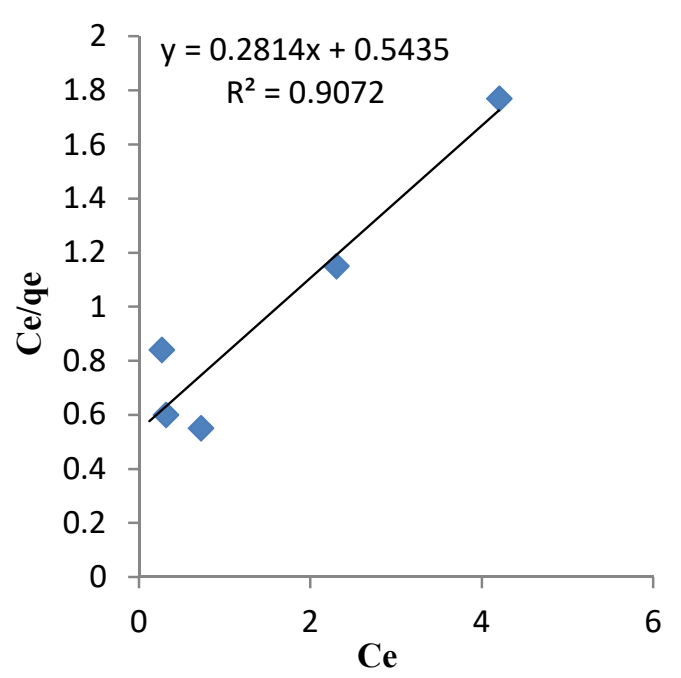

Fig 5 Langmuir isotherm for the biosorption of $\mathrm{Zn}$ (II) by alginate immobilized Aspergillus fumigatus

Conclusion: The results of the batch adsorption processes undertaken in this study showed that the removal efficiency of the metals was mostly $\mathrm{pH}-$ dependent. There was also an increase in efficiency with increase in adsorbent dosage. The adsorption isotherms plotted for the results showed that the experimental data fitted the Langmuir isotherm which indicates a monolayer adsorption. These results indicate that zinc metal removal by biomass of Penicillium $s p$ immobilized in alginate is a low cost wastewater treatment option and can be effectively used in small scale treatment plants. 
Acknowledgement: We will like to thank Mr. Mikailu of National Institute for Leather Science and Technology, NILEST, Zaria for assistance in the identification and growth of the Aspergillus fumigatus.

\section{REFERENCES}

Ahalya, N; Ramchanra, TV; Kanamodi, R D (2003). Biosorption of heavy metals. Res. J. Chem. Environ. 7: 71- 78

Amuda, OS; Giwa, A A; Bello, I A (2007). Removal of heavy metal from industrial wastewater using modified activated coconut shell carbon. Biochem. Engg. J. 36(2): $174-181$

Arias, A; Sen, T K (2009). Removal of zinc metal ion $\left(\mathrm{Zn}^{2+}\right)$ from it aqueous solution by kaolin clay mineral: A kinetic and equilibrium study. Colloid. Surf. A. 348: $100-108$

Babel, S; Opiso, E M (2007). Removal of chromium from synthetic wastewater by sorption onto volcanic ash soil. Int. J. Environ. Sci. Tech. 4(1): 99-107

Davis, TA; Volesky, B; Mucci, A (2003). A review of the biochemistry of heavy metal biosorption by brown algae. Water Res. 37: $4311-4330$

Dong, X (2004). A comparative study of $\mathrm{Cu}$ (II) biosorption on $\mathrm{Ca}$ - alginate immobilized, live and inactivated Cladosporium sp. J. Environ. Biol. 5: 337-341

Garg, V K; Gupta, R; Kumar, R; Gupta, R K (2004). Adsorption of chromium from aqueous solution on treated sawdust. Bioresour. Technol. 92: 79 81
Gok, C; Aytas, S (2009). Biosorption of uranium (VI) from aqueous solution using calcium alginate beads. J. Hazard. Mater. 168(1): $369-375$

Horsfall, M; Spiff, A I; Abia, A A (2004). Studies on the influence of mercaptoacetic acid (MAA) modification of cassava (Manihot esculenta) waste biomass on the adsorption of $\mathrm{Cu}^{2+}$ and $\mathrm{Cd}^{2+}$ from aqueous solution. Bull. Kor. Chem. Soc. 25(7): 969-976

Kapoor, A. and Viraraghavan, T. (1997). Heavy metal biosorption sites in Aspergillus niger. Bioresour. Technol. 61: 221 - 227

Pundir, R; Dastidar, MG. (2010). Recovery of $\mathrm{Cu}$ and $\mathrm{Ni}$ ions from metal - loaded fungal biomass using acidic eluent. Int. J. Chem. Environ. Engg. 1(1): 63-66

Spinti, M; Zhuang, H; Trujillo, E M. (1995). Evaluation of immobilized biomass beads for removing heavy metals from wastewaters. Water Environ. Res. 67: 943 - 954

Srinavasa, VY; Popuri, R; Boddu, MV; Krishnaiah, A (2008). Modified chitosan and CA biopolymer sorbents for removal of nickel (II) through adsorption. Carbohyd. Poly. 72(2): $261-271$

Wang, J; Chen, C (2009). Biosorbents for heavy metals removal and their future. Biotechnol. Adv. 27: $195-226$ 